\title{
Comments on Brodie and Post: Climate-driven declines in wolverine populations: causal connection or spurious correlation?
}

\author{
Kevin S. McKelvey • Eric C. Lofroth • \\ Jeffrey P. Copeland $\cdot$ Keith B. Aubry • \\ Audrey J. Magoun
}

Received: 5 April 2010/ Accepted: 13 June 2010/Published online: 22 September 2010

(C) The Author(s) 2010. This article is published with open access at Springerlink.com

\begin{abstract}
The recent paper by Brodie and Post ("Nonlinear responses of wolverine populations to declining winter snowpack", Popul Ecol 52:279-287, 2010) reports conclusions that are unsupportable, in our opinion, due to both mis-interpretations of current knowledge regarding the wolverine's (Gulo gulo) association with snow, and the uncritical use of harvest data to index wolverine populations. The authors argue that, because the wolverine is a snowdependent species, average annual provincial snowfall, based on weather station data, can be expected to correlate strongly and positively with wolverine population numbers, which in turn can be accurately indexed by trapper harvests. Thus, correlations between declines in wolverine harvests and declining average snowpack are interpreted to reflect a climate-driven decrease in wolverine populations. This conclusion overstates the nature of the wolverine's association with snow, and makes unsupportable assumptions about the reliability of harvest data as a proxy for population size.
\end{abstract}

A reply to this "notes and comments" is available at doi:10.1007/s10144-010-0243-4.

\section{K. S. McKelvey $(\varangle) \cdot$ J. P. Copeland}

Rocky Mountain Research Station, US Forest Service, 800 E. Beckwith, Missoula, MT 59801, USA

e-mail: kmckelvey@fs.fed.us

E. C. Lofroth

Ministry of Environment, P.O. Box 9338,

Victoria, BC V8W9M1, Canada

\section{K. B. Aubry}

Pacific Northwest Research Station, US Forest Service, 3625 93rd Ave. SW, Olympia, WA 98512, USA

\section{A. J. Magoun}

Wildlife Research and Management, 3680 Non Road, Fairbanks, AK 99709, USA
Keywords Climate change Gulo gulo $\cdot$ Harvest data . Trapping

Snow has long been recognized as a key component of wolverine (Gulo gulo) habitat (Hatler 1989; Banci 1994). Snow dens provide offspring with protection from predators and an insulation advantage (Pulliainen 1968; Magoun and Copeland 1998). Recently, we showed that wolverines appear to be restricted to cold areas represented by the availability and distribution of spring (mid-April to midMay) snow cover (Copeland et al. 2010). Not only do wolverines require spring snow cover for reproductive dens, but year-round habitat use (Copeland et al. 2010) and travel routes associated with successful dispersals (Schwartz et al. 2009) are also confined almost exclusively to this climatic zone. Moreover, both historical occurrence records (Aubry et al. 2007) and genetic patterns (Schwartz et al. 2007) indicate that observed habitat-use patterns in the southern portion of their range in North America are not recent anthropogenic artifacts. There is no historical or current evidence that wolverines can persist outside climatically cold areas with spring snowpack. All the findings to date indicate that a warming climate would likely alter the nature and/or geographic extent of wolverine habitat on a world-wide scale. Although we agree that global warming can be expected to adversely affect wolverine populations, we contend that the data Brodie and Post (2010) used in their analyses cannot be used to investigate this hypothesis.

Climate change is a gradual process, and its effects on habitat suitability for wolverines and other organisms will vary geographically depending on a broad array of covariates occurring at multiple spatial scales. Additionally, it co-occurs with rapid anthropogenic changes which, in turn, 
may also be correlated with changing climates. Consequently, the kinds of correlative relationships described in Brodie and Post (2010) need to be explored in detail to ascertain the likelihood that such observations are causal in nature. However, Brodie and Post (2010) make no attempt to determine whether regional snow averages accurately describe the snow conditions where wolverines live, no attempt is made to confirm that the trapping data used provides a meaningful population index, and no attempt is made to explore whether the observed trends could be due to causes other than climate.

Perhaps the most significant error in their analyses is the assumption that wolverine harvest levels reported by trappers provide a reliable surrogate for population size and that population dynamics can be inferred from these data. Although the authors note that the Canada lynx/snowshoe hare cycle was first explored using trapping data, for most species, trapping data are considered an unreliable index of population size. As noted by Lambin et al. (2002), even snowshoe hare data has its problems when used in this context. Based on intensive studies in Yukon, Canada, the amplitude of snowshoe hare densities was approximately 14-fold, whereas fur-return statistics suggested amplitudes in excess of 1,000-fold. The degree of unreliability associated with trapping data varies from species to species, and on the research objectives for which such data are used. For example, lynx/hare harvest data have proved reliable for indicating the timing of population pulses but, as Lambin et al. (2002) noted, do not provide reliable indices of population size. Trapping harvest is based on trapper interest (effort) and species availability. Trapping effort can be affected by many factors including fur price, weather conditions (which can, in turn, influence access), and costs (e.g., fuel). Species availability (to trappers) may reflect abundance, but can also be influenced by the degree of access trappers have to that species' habitat. For these reasons, harvest data alone are generally not considered a reliable estimate of population trends (see review in Gese 2001). For harvest data to provide a direct and reliable index of population size, trapper effort and effectiveness need to be constant and this has not been the case for wolverines. Historically, wolverine harvests have been correlated with pelt price (1919-1970, $r=0.45$; Novak et al. 1987, Fig. 1) but recent high prices have failed to produce more wolverines (Fig. 1). The reason that relatively few wolverines are harvested despite record high prices probably reflects decreasing interest in trapping. In British Columbia, the number of trapping licenses sold and the total number of registered traplines reporting any harvest of furbearers have both declined steadily from 1986 to 2005 (Figs. 2 and 3). Note that these data pertain to the trapping of all species. Thus, if no harvest is reported for a registered trap line, it means that the trapper did not run the

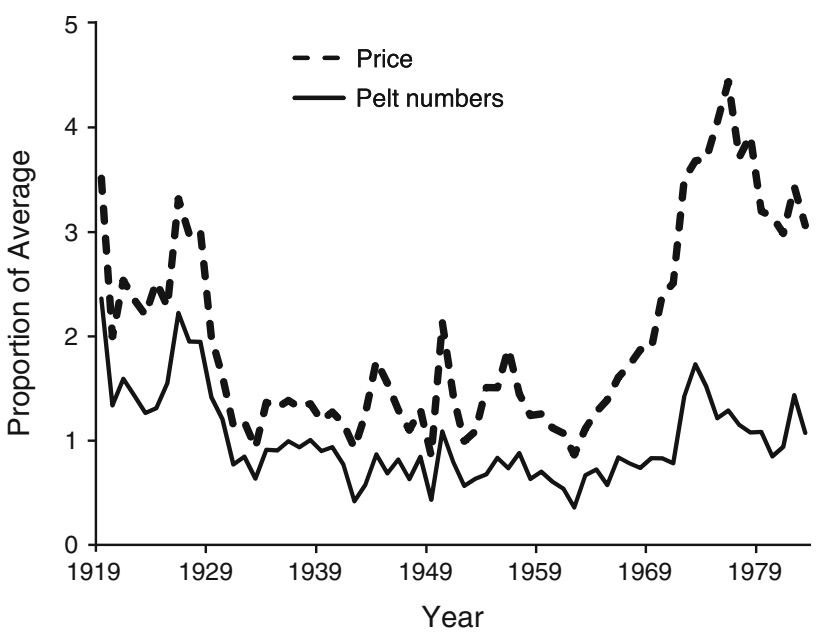

Fig. 1 Trends in price and wolverine (Gulo gulo) harvest for Canada from 1919/1920 to 1983/1984; data from Novak et al. (1987). Pelt prices were in Canadian dollars and were adjusted for inflation by Novak et al. (1987). Both pelt prices and harvest numbers are presented as proportions relative to their respective arithmetic means across the time period

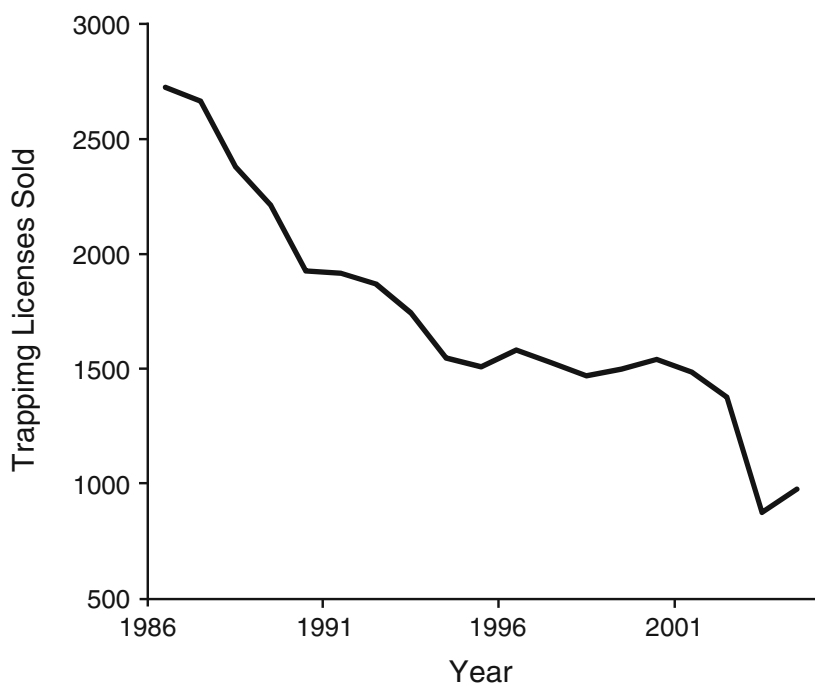

Fig. 2 Trapping licenses sold in British Columbia, Canada, from 1986/1987 to 2004/2005. Data from British Columbia Ministry of Environment Wildfur Data System

trap line that year. Record-keeping practices in British Columbia changed in 1985; prior to this time, data on registered trap lines and license sales are incomplete. Because records are not available, we cannot derive these same understandings for earlier time periods (e.g., Novak et al. 1987, Fig. 1). However, judging from the patterns from 1986 to 2005 (Figs. 2 and 3) and given continued high prices (Fig. 4), it is likely that trapping effort began to decrease around 1970, when historical correlations between harvest and pelt price break down. In short, wolverine harvest levels in the recent past have been strongly 


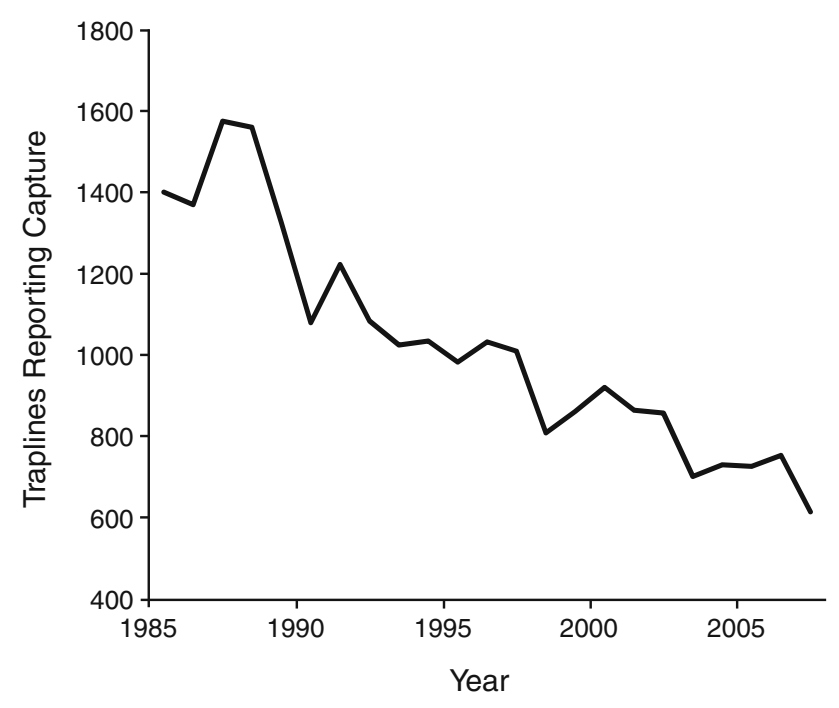

Fig. 3 Number of registered trap lines reporting harvest in British Columbia from 1985/1986 to 2006/2007. Data from British Columbia Ministry of Environment Wildfur Data System

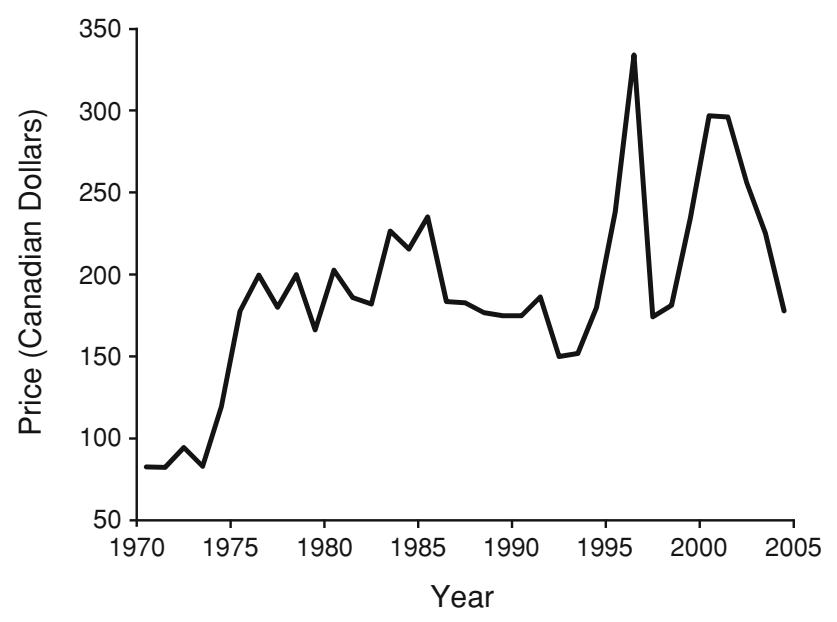

Fig. 4 Average wolverine pelt prices from 1970/1971 to 2004/2005. Data represent mean annual pelt prices reported by licensed British Columbia fur traders. Data from British Columbia Ministry of Environment Wildfur Data System (not adjusted for inflation)

affected by anthropogenic factors that are largely independent of population size. Importantly, across the period of interest (at least for British Columbia), general trapping effort is now less than half what it was in 1985. Given this decrease in effort, a decrease in harvest levels is to be expected regardless of population size, climate change, or anything else.

Additionally, there is no corroborative evidence to support their claim that wolverines are declining. Wolverine populations are generally described as stable or increasing across Canada (Lofroth and Krebs 2007; Slough 2007). Krebs et al. (2004) performed a vital rate meta-analysis of 12 North American wolverine studies conducted between
1972 and 2001, and concluded that unharvested populations were growing ( $\lambda \sim 1.06)$. In the contiguous US, wolverine populations appear to have increased during the last 50 years, as indicated by recolonization of areas from which they were previously extirpated (Aubry et al. 2007). Recently, dispersing males have been documented in California (McKelvey et al. 2008; Moriarty et al. 2009) and Colorado (Inman et al. 2010). These are the first verifiable wolverine records in these states since 1924 and 1919, respectively (Aubry et al. 2007), and are likely associated with current population expansions such as the recent observed recolonization of the northern Cascade Range in Washington (K. Aubry, unpublished data).

Brodie and Post (2010) do document a correlationboth the number of wolverines trapped annually in Canada and average snowfall have been declining in recent years. But the conclusion that this correlation reflects a causal relationship cannot be inferred from the data presented. Populations of wolverines may or may not have declined during this period. Population changes, if they occurred, may or may not have been due to shifting climate. Thus, the authors' claim that they have detected a climate-driven decline in wolverine populations using these data is, in our opinion, unsupportable.

Acknowledgments We thank Michael Schwartz, John Squires, and two anonymous reviewers for helpful comments on previous drafts of this manuscript.

Open Access This article is distributed under the terms of the Creative Commons Attribution Noncommercial License which permits any noncommercial use, distribution, and reproduction in any medium, provided the original author(s) and source are credited.

\section{References}

Aubry KB, McKelvey KS, Copeland JP (2007) Geographic distribution and broadscale habitat relations of the wolverine in the contiguous United States. J Wildl Manage 71:2147-2158

Banci VA (1994) Wolverine. In: Ruggiero LF, Aubry KB, Buskirk SW, Lyon LJ, Zielinski WJ (eds) The scientific basis for conserving forest carnivores: American marten, fisher, lynx and wolverine in the western United States. USDA Forest Service, Rocky Mountain Forest and Range Experiment Station, General Technical Report RM-254. Fort Collins, Colorado, pp 99-127

Brodie JF, Post E (2010) Nonlinear responses of wolverine populations to declining winter snowpack. Popul Ecol 52:279-287

Copeland JP, McKelvey KS, Aubry KB, Landa A, Persson J, Inman RM, Krebs J, Lofroth E, Golden H, Squires JR, Magoun A, Schwartz MK, Wilmot J, Copeland CL, Yates RE, Kojola I, May $\mathrm{R}$ (2010) The bioclimatic envelope of the wolverine (Gulo gulo): do climatic constraints limit its geographic distribution? Can J Zool 88:233-246

Gese E (2001) Monitoring of terrestrial carnivore populations. In: Gittleman JL, Funk SM, MacDonald DW, Wayne RK (eds) Carnivore conservation. Cambridge University Press, Cambridge, pp 372-396 
Hatler DF (1989) A wolverine management strategy for British Columbia. Wildlife Bulletin B-60. Ministry of Environment, Wildlife Branch, Victoria

Inman RM, Packila M, Inman K, Aber B, Spence R, McCauley D (2010) Greater Yellowstone wolverine program. Unpublished report, Wildlife Conservation Society. Ennis, Montana

Krebs J, Lofroth E, Copeland J, Banci V, Golden H, Magoun A, Mulders R, Shults B (2004) Synthesis of survival rates and causes of mortality in North American wolverines. J Wildl Manage 68:493-502

Lambin X, Krebs CJ, Moss R, Yoccuz NG (2002) Population cycles: inferences from experimental, modelling, and time series approaches. In: Berryman A (ed) Population cycles: the case for trophic interactions. Oxford University Press, New York, pp 155-176

Lofroth EC, Krebs J (2007) The abundance and distribution of wolverines in British Columbia, Canada. J Wildl Manage 71:2159-2169

Magoun AJ, Copeland JP (1998) Characteristics of wolverine reproductive den sites. J Wildl Manage 62:1313-1320

McKelvey KS, Aubry KB, Schwartz MK (2008) The use of anecdotal occurrence data for rare or elusive species: the illusion of reality and a call for evidentiary standards. Bioscience 58:549-555
Moriarty KM, Zielinski WJ, Gonzalez AG, Dawson TE, Boatner KM, Wilson CA, Schlexer FV, Pilgrim KL, Copeland JP, Schwartz MK (2009) Wolverine confirmation in California after nearly a century: native or long-distance immigrant? Northwest Sci $83: 154-162$

Novak M, Obbard ME, James JG, Newman R, Booth A, Satterthwaite AJ, Linscombe G (1987) Furbearer harvests in North America, 1600-1984. Ministry of Natural Resources, Ontario

Pulliainen E (1968) Breeding biology of the wolverine (Gulo gulo L.) in Finland. Ann Zool Fenn 5:338-344

Schwartz MK, Aubry KB, McKelvey KS, Pilgrim KL, Copeland JP, Squires JR, Inman RM, Wisely SM, Ruggiero LF (2007) Inferring geographic isolation of wolverines in California using historical DNA. J Wildl Manage 71:2170-2179

Schwartz MK, Copeland JP, Anderson NJ, Squires JR, Inman RM, McKelvey KS, Pilgrim KL, Waits LP, Cushman SA (2009) Wolverine gene flow across a narrow climatic niche. Ecology 90:3222-3232

Slough BG (2007) Status of the wolverine (Gulo gulo) in Canada. Wildlife Biol 13(Suppl 2):76-82 